\title{
RATIO OF CD68/CD163 IN BREAST CARCINOMA WITH AND WITHOUT AXILLARY LYMPH NODE METASTATIC
}

\author{
Priangga Adi Wiratama, Willy Sandhika \\ Department of Anatomic Pathology, Faculty of Medicine, Universitas Airlangga/Dr. Soetomo Hospital, Surabaya, \\ Indonesia
}

\section{ABSTRACT}

Tumor and its microenvironment can interact each other. Macrophage is part of tumor microenvironment. New drugs targeting specific superficial receptor of macrophage or cytokine of macrophage polarization have been found. Therefore, macrophage phenotype and its ratio of M1/M2 macrophage need to be identified. This identification could lead us to prognose breast cancer and monitor its therapy. Analytical observational study with cross sectional approach, conducted on paraffin block sample of breast carcinoma from Anatomical Pathology Laboratory of Dr. Soetomo General Hospital. The samples divided into four groups based on nodal metastasis staging (NO, N1, N2, and N3) and stained with antibody against CD68 and CD163. The ratio of CD68 and CD163 were analyzed with Anova test. There were difference expression of CD68 as M1 macrophage marker in various axillary node metastasis groups $(p=0.015)$. There were difference ratio of CD68 as M1 macrophage marker and CD163 as M2 macrophage marker in various axillary node metastasis groups $(p=0.005)$. There were difference ratio of macrophage M1 and macrophage M2 between NO and N3 group, N2 and N3 group also.

Keywords: Macrophage M1; Macrophage M2; breast carcinoma

\section{ABSTRAK}

Tumor dan lingkungan tumor dapat saling berinteraksi. Makrofag merupakan bagian dari lingkungan mikro tumor. Obatobatan baru yang bekerja dengan target spesifik pada reseptor permukaan makrofag maupun pada sitokin pemicu polarisasi telah ditemukan. Oleh karena itu, identifikasi makrofag serta perhitungan rasio makrofag M2 terhadap jumlah makrofag M1 pada karsinoma payudara bisa menjadi celah untuk kepentingan prognostik maupun pemantauan efek terapi. Penelitian observasional analitik dilakukan pada sampel blok paraffin karsinoma payudara, dibagi dalam kelompok NO, N1, N2, dan N3 dari laboratorium Patologi Anatomi RSUD Dr.Sutomo. Sampel dipulas secara imunohistokimia dengan antibodi CD68 dan CD163. Hasil penelitian dianalisis menggunakan uji Anova. Hasil penelitian menunjukkan, terdapat perbedaan ekspresi makrofag M1 antara kelompok metastasis kelenjar getah bening aksila dan tanpa metastasis kelenjar getah bening aksila ( $p=$ 0,015). Terdapat perbedaan rasio ekspresi makrofag M1 dan makrofag M2 antar kelompok metastasis kelenjar getah bening aksila dan tanpa metasasis kelenjar getah bening aksila $(p=0,005)$. Selain itu, terdapat pula perbedaan rasio rerata makrofag M1 dan makrofag M2 antara kelompok metastasis kelenjar getah bening aksila N2 dan N3 serta kelompok NO dan N3.

Kata kunci: Makrofag M1; makrofag M2; karsinoma payudara

Correspondence: Willy Sandhika, Department of Anatomic Pathology, Universitas Airlangga, Surabaya, Indonesia. E-mail: willysand@fk.unair.ac.id

pISSN:2355-8393 • eISSN: 2599-056x • doi: 10.20473/fmi.v56i1.18446

- Fol Med Indones. 2020;56:19-23 • Received 27 Dec $2017 \bullet$ Accepted 17 May 2018

- Open access under CC-BY-NC-SA license • Available at https://e-journal.unair.ac.id/FMI/

\section{INTRODUCTION}

Fourty years ago, tumor-centered cancer therapy is common. In middle of 80's, researcher found that tumor and its microenvironment can interact each other to support tumor progression. Despite of this fact, thought of acute inflamation in tumor microenvironment were proposed by Virchow in 1867 (Balkwill and Mantovani, 2010). Macrophages is one of cellular component of tumor microenvironment. Macrophages display remarkable plasticity and can change their physiology in response to environmental cues. These changes can give rise to different populations of cells with distinct functions (Mosser 2003). M1 macrophage and M2 macrophage are extreme phase of these spectrum. M1 macrophage has pro-inflammation role. In the other side, M2 macrophage is associated with tumorassociated macrophage (TAM). TAM has key role in tumor progression and invasion (Obeid et al 2013). TAM can suppress inflammatory reaction and has pro- 
tumor role. New drugs targeting specific superficial receptor of macrophage or cytokine of macrophage polarization have been found. Therefore, macrophage phenotype and its ratio of M1/M2 macrophage need to be identified. This identification could lead us to prognose breast carcinoma and monitor its therapy. In this study, CD68 as M1 macrophage marker and CD163 as M2 macrophage marker expression in breast carcinoma were done to evaluate their roles in various group of axillary nodal metastasis

\section{MATERIALS AND METHODS}

Analytical observational study with cross sectional approach, conducted on paraffin block sample of breast carcinoma from Anatomical Pathology Laboratory of Dr. Soetomo General Hospital. The samples divided into four groups based on nodal metastasis staging (N0, $\mathrm{N} 1, \mathrm{~N} 2$, and N3) and stained with antibody against CD68 and CD163. Total samples used was 44 samples, 11 samples in each group. Immunohistochemistry with antibody against CD68 and CD163 was done in all samples. This study used monoclonal antibody for CD68 (Mob167) from Diagnostic BioSystem with 1:100 dilution, positivity evaluated in cytoplasm of tumor cells. CD163 was evaluated using monoclonal antibody for CD163 (Mob460) from Diagnostic BioSystem with 1:50 dilution, positivity evaluated also in cytoplasm of tumor cells. Both expressions then counted in five hotspots on 400x magnification. Mean of five hotspots then recorded to produce ratio of $\mathrm{M} 1 / \mathrm{M} 2$ in each sample. Mean of M1 macrophage and M2 macrophage, and also ratio of $\mathrm{M} 1 / \mathrm{M} 2$ in axillary nodal metastasis groups N0, N1, N2 and N3 then analyzed with Anova test. $\mathrm{p}<0,05$ is significant.

\section{RESULTS}

Characteristics of all patients (samples) are summarized in Table 1 . Mean age was 54,32 tahun $\pm 10,64$ years old, with largest frequency in 45-65 years old range. Most of samples were stage 2 and grade 3 .

Anova test (Table 2) found significant difference of mean of CD68 as M1 macrophage marker in various axillary nodal metastasis of breast carcinoma in general, with $\mathrm{p}=0,015(\mathrm{p} \leq 0,05)$. The mean of CD68 were only significantly different in N0 compared to N1 and N1 compared to $\mathrm{N} 2$.

Anova test (Table 3) found there is no significant difference of mean of CD163 as M2 macrophage marker in various metastasis group of breast carcinoma in general, with $\mathrm{p}=0.077(\mathrm{p} \leq 0.05)$.

Ratio of mean of CD68 and CD163 were analyzed. Anova test (Table 4) found significant difference of ratio of mean of CD68 and CD163 in various axillary nodal metastasis of breast carcinoma in general, with $p=0.005 \quad(p \leq 0.05)$. The ratio of mean of CD68 and CD163 were only significantly different in N0 compared to $\mathrm{N} 3$ and $\mathrm{N} 2$ compared to $\mathrm{N} 3$.

Table 1. Clinicopathological characteristics of patients and tumors

\begin{tabular}{ccccccc}
\hline \multirow{2}{*}{ Parameters } & \multicolumn{3}{c}{ Dukes stage } & \multicolumn{3}{c}{ Total } \\
\cline { 2 - 6 } & N0 & N1 & N2 & N3 & Quantity & Percentage(\%) \\
\hline Age (y.o) & 1 & 0 & 0 & 0 & 1 & 2.2 \\
$<35$ & 2 & 0 & 3 & 3 & 8 & 18.18 \\
$>35-45$ & 4 & 6 & 3 & 3 & 16 & 36.36 \\
$>45-55$ & 4 & 3 & 4 & 5 & 16 & 36.36 \\
$>55-65$ & 1 & 1 & 1 & 0 & 3 & 6.8 \\
$>65$ & 2 & 3 & 0 & 1 & 6 & 13.64 \\
Tumor Staging & & 5 & 6 & 1 & 20 & 45.45 \\
T1 & 0 & 2 & 2 & 4 & 8 & 18.18 \\
T2 & 1 & 1 & 3 & 5 & 10 & 22.72 \\
T3 & & & & & & 6.8 \\
T4 & 1 & 2 & 0 & 0 & 3 & 31.81 \\
Tumor Grading & & 2 & 5 & 14 & 61.36 \\
1 & 3 & 4 & 9 & 6 & 27 & \\
\hline
\end{tabular}


Table 2. CD68 (M1 macrophage) in various nodal metastasis group

\begin{tabular}{ccccc}
\hline Nodal & \multirow{3}{c}{ CD68 } \\
\cline { 3 - 5 } Metastasis & $\mathrm{n}$ & Mean & $\mathrm{SD}$ & $\mathrm{p}$ \\
\hline $\mathrm{N} 0$ & 11 & $16,64^{\mathrm{b}}$ & 4.10 & \\
$\mathrm{~N} 1$ & 11 & $9.91^{\mathrm{a}}$ & 6.34 & $0.015^{*}$ \\
$\mathrm{~N} 2$ & 11 & $15.45^{\mathrm{b}}$ & 2.03 & \\
$\mathrm{~N} 3$ & 11 & $12.27^{\mathrm{ab}}$ & 5.21 & \\
\hline Notes: *significant in $\alpha=0.05$ (Anova test) \\
a,b same superscript showed no difference between \\
groups (post-hoc LSD test)
\end{tabular}

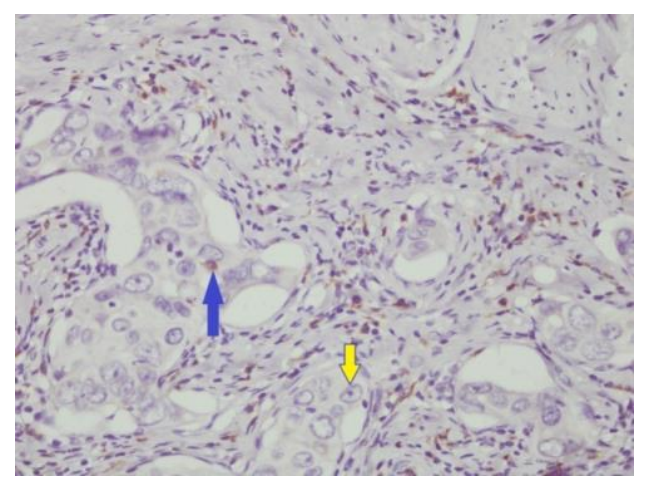

Fig. 1. CD68 was positively stained in macrophage cells cytoplasm (blue arrow) and negatively stained in tumor cells cytoplasm (yellow arrow).

Table 3. CD163 (M2 Macrophage) in various nodal metastasis group

\begin{tabular}{ccccc}
\hline Nodal & \multirow{2}{*}{$\mathrm{n}$} & \multicolumn{3}{c}{ CD163 } \\
\cline { 3 - 5 } Metastasis & & Mean & SD & $\mathrm{p}$ \\
\hline $\mathrm{N} 0$ & 11 & $14.27^{\mathrm{a}}$ & 7.97 & \\
$\mathrm{~N} 1$ & 11 & $11.45^{\mathrm{a}}$ & 4.54 & $0.077^{*}$ \\
$\mathrm{~N} 2$ & 11 & $14.36^{\mathrm{a}}$ & 4.05 & \\
$\mathrm{~N} 3$ & 11 & $17.64^{\mathrm{a}}$ & 3.66 & \\
\hline Notes: & $*$ significant in $\alpha=0.05$ (Anova test) \\
& ${ }^{\text {a }}$ same superscript showed no difference between groups \\
(post-hoc LSD test)
\end{tabular}

Table 4. Ratio CD68/CD163 in various nodal metastasis group

\begin{tabular}{ccccc}
\hline Nodal & \multirow{2}{*}{ Retio CD68/CD163 } \\
\cline { 3 - 5 } Metastasis & & Mean & SD & $\mathrm{p}$ \\
\hline N0 & 11 & $1.42^{\mathrm{b}}$ & 0.65 & \\
N1 & 11 & $0.97^{\mathrm{ab}}$ & 0.41 & $0.005^{*}$ \\
$\mathrm{~N} 2$ & 11 & $1.11^{\mathrm{b}}$ & 0.37 & \\
N3 & 11 & $0.69^{\mathrm{a}}$ & 0.28 & \\
\hline Notes: *significant in $\alpha=0.05$ (Anova test) \\
a,bsame superscript showed no difference between groups \\
(post-hoc LSD test)
\end{tabular}

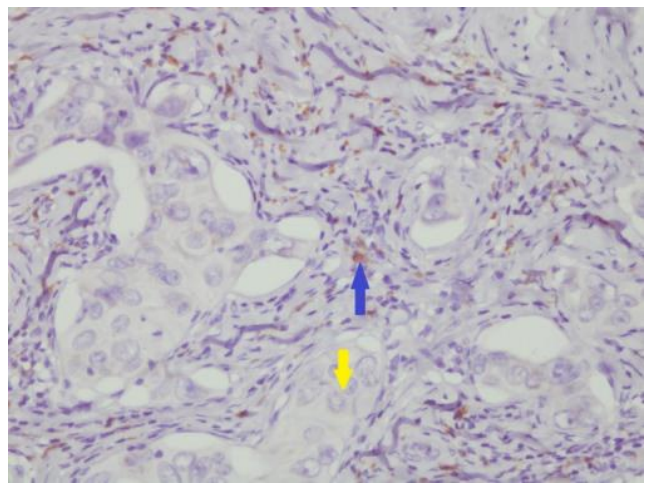

Fig. 2. CD163 was positively stained in macrophage cells cytoplasm (blue arrow) and negatively stained in tumor cells cytoplasm (yellow arrow).

\section{DISCUSSION}

\section{Characteristics of samples}

This study used 44 paraffin blocks samples of invasive carcinoma of no special type of breast. Invasive carcinoma of no special type was chosen because it is the most common subtypes of breast cancer. Nodal metastasis was chosen because it could represent progression of disease and disruption of microenvironment homeostasis. In this study, mean age was 54,32 $\pm 10,64$ years old, mostly in 45-55 and 55-65 years old groups, it is concordant with the literatures facts that breast carcinoma mostly occurred in older group of patient.

\section{M1 macrophage pro-inflammation role in tumor microenvironment}

In physiologic condition, macrophage can be polarized and shows heterogeneity of role according to polarization spectrum (Sica \& Mantovani 2012). TLR and IFN-gamma induced polarization of naive macrophage to be M1 macrophage. M1 macrophage stimulates acute inflammation as response of tissue injury. CD68 as M1 macrophage marker in this study showed fluctuative mean and there were only significant difference in $\mathrm{N} 0$ compared to $\mathrm{N} 1$ group and $\mathrm{N} 1$ compared to N2. These empiric fact could be caused by consistent inflammation process. There is "neverending" inflammation tumor microenvironment (Tu et al 2016). Hypoxic area of tumor can produce damageassociated molecule pattern (DAMP) that be recognized by toll-like receptor (TLR) of M1 macrophage (Srikrishna \& Freeze 2009). Activation of TLR M1 macrophage leads activation of NF-KB pathway and could release pro-inflammation cytokine, such as TNF- 
alfa, reactive oxygen species (ROS) and nitric oxyde (NO). In the other side, tumor cells also releases macrophage colony stimulating factor (CSF-1) and recruits monocyte-derived macrophage into tumor microenvironment (Qian \& Pollard 2010).

\section{M2 Macrophage anti-inflammation role in tumor microenvironment}

In physiologic condition, IL-4, IL-13 and glucocorticoid derive macrophage polarization to be M2 macrophage (Roszer 2015). M2 macrophage stimulates wound healing and vascularization (Lucas et al 2010). M2 macrophage has responsibility in anti-inflammation process by releasing of TGF-beta and IL-10. In this study, there was no significant difference between various group of axillary nodal metastasis. Although, there were increasing of mean of M2 macrophage in N1, $\mathrm{N} 2$ and N3 groups. These empiric fact could be caused by DAMP recognition by receptor advanced glycation endproduct (RAGE) on M2 macrophage (Srikrishna \& Freeze 2009). This recognition activated JAK/STAT pathway then stimulated releasing of anti-inflamation cytokine TGF-beta (Gordon 2003). TGF-beta could suppress NF-KB pathway. These interaction could lead domination of anti-inflammation effect along with nodal metastasis status.

\section{Ratio of M1/M2 role as macrophage polarization marker}

M1 and M2 is simplified phenotyping among macrophage polarization spectrum. Macrophage could lose their M1 phenotype, in the same time with, arising of M2 phenotype. Ratio of M1/M2 would be more predictive than single use of M1 or M2 macrophage characterization. In this study, there was significant difference M1/M2 ratio in N0 compared to N3 and N2 compared to N3. This result has concordace with another previous research. M2/M1 ratio correlated with higher grade and stadium of bladder cancer (Takeuchi et al 2015). M1/M2 ratio correlated with poor prognosis in ovarian cancer than single use of M1 macrophage density (Yafei et al 2016). M1/M2 ratio also showed difference in nodal metastasis and non-nodal metastasis of esophageal carcinoma (Cao et al 2015) and colorectal carcinoma (Cui et al 2013).

\section{CONCLUSION}

There was significant difference of CD68 expression as M1 macrophage marker in various axillary nodal metastasis groups and no significant difference of CD163 expression as M2 macrophage marker in various axillary nodal metastasis groups. Nevertheless, there was significant difference of $\mathrm{M} 1 / \mathrm{M} 2$ ratio in various axillary nodal metastasis groups

\section{ACKNOWLEDGMENT}

The authors thank the Faculty of Medicine Anatomical Pathology Laboratory of Universitas Airlangga shared resource core facilities and Biozatix for providing antibodies reagent.

\section{REFERENCES}

Cao W, Peters JH, Nieman D (2015). Macrophage subtype predicts lymph node metastasis in oesophageal adenocarcinoma and promotes cancer cell invasion in vitro. British Journal of Cancer 113, 73846

Cui YL, Li HK, Zhou HY, Zhang T, et al (2013). Correlations of tumor-associated macrophage subtypes with liver metastases of colorectal cancer. Asian Pacific Journal of Cancer Preventio 14, 1003-7

Gordon S (2003) Alternative activation of macrophages. National Review Immunology 3, 23-35

Lucas T, Waisman A, Ranjan R, et al (2010). Differential roles of macrophages in diverse phases of skin repair. The Journal of Immunology 184, 39643977

Mosser DM (2003). The many faces of macrophage activation. J Leukoc Biol 73, 209-212

Obeid E, Nanda R, Fu, YX, Olopade OI (2013). The role of tumor-associated macrophage in breast cancer progression. International Journal of Oncology 43, 512.

Qian B-Z, Pollard JW (2010). Macrophage diversity enhances tumor progression and metastasis. Cell 141, $39-51$

Roszer T (2015). Understanding mysterious M2 macrophage through activation marker and effector mechanism. Hindawi Publishing Corporation, Mediator of Inflammation 2015

Sica A, Mantovani A (2012). Macrophage plasticity and polarization: in vivo veritas. The Journal of Clinical Investigation 122, 787-95

Srikrishna G, Freeze H (2009). Endogenous damageassociated molecular pattern molecules at the crossroads of inflammation and cancer. Neoplasia 11, 615-28

Takeuchi H, Michio T, Ayako T, et al (2015). Predominance of M2-polarized macrophages in bladder cancer affects angiogenesis, tumor grade and invasiveness. Oncology 11, 3403-3408

Tu Z, Xiao R, Xiong J, et al (2016). CCR9 in cancer: oncogenic role and therapeutic targeting. Journal of Hematology and Oncology 9, 10 
Yafei Z, Jun G, Guolan G (2016). Correlation between macrophage infiltration and prognosis of ovarian cancer-a preliminary study. Biomedical Research (0970-938X) 27, p305-312. 